\title{
Cholinesterase inhibitory activities of neuroprotective fraction derived from red alga Gracilaria manilaensis
}

\author{
Jun-Rui Pang' ${ }^{1}$ Sher-Wei How ${ }^{2}$, Kah-Hui Wong ${ }^{3}$, Siew-Huah Lim ${ }^{4}$, Siew-Moi Phang ${ }^{5,6}$, Yoon-Yen Yow ${ }^{1, *}$ \\ ${ }^{1}$ Department of Biological Sciences, School of Medical and Life Sciences, Sunway University, Bandar Sunway, 47500 Selangor Darul Ehsan, Malaysia \\ ${ }^{2}$ Department of Molecular Medicine and Pathology, Faculty of Medical and Health Science, The University of Auckland, Aukland CBD, Aukland 1010, \\ New Zealand \\ ${ }^{3}$ Department of Anatomy, Faculty of Medicine, Universiti Malaya, 50603 Kuala Lumpur, Malaysia \\ ${ }^{4}$ Department of Chemistry, Faculty of Sciences, Universiti Malaya, 50603 Kuala Lumpur, Malaysia \\ ${ }^{5}$ Faculty of Applied Sciences, UCSI University, Cheras 56000 Kuala Lumpur, Malaysia \\ ${ }^{6}$ Institute of Ocean and Earth Sciences, University of Malaya, Kuala Lumpur, Malaysia
}

\begin{abstract}
Anti-cholinesterase (ChE)s are commonly prescribed as the symptomatic treatment of Alzheimer's disease. They are applied to prevent the breakdown of neurotransmitter acetylcholine (ACh) that bind to muscarinic and nicotinic receptors in the synaptic cleft. Seaweeds are one of the richest sources of bioactive compounds for both nutraceuticals and pharmacognosy applications. This study aimed to determine the anti-ChEs activity of Gracilaria manilaensis, one of the red seaweeds notables for its economic importance as food and raw materials for agar production. Methanol extracts (GMM) of G. manilaensis were prepared through maceration, and further purified with column chromatography into a semi-pure fraction. Ellman assay was carried out to determine the anti-acetylcholinesterase (AChE) and anti-butyrylcholinesterase (BuChE) activities of extracts and fractions. Lineweaver-Burk plot analysis was carried out to determine the inhibition kinetic of potent extract and fraction. Major compound(s) from the most potent fraction was determined by liquid chromatography-mass spectrometry (LCMS). GMM and fraction G (GMMG) showed significant inhibitory activity $A C h E$ with $\mathrm{EC}_{50}$ of $2.6 \mathrm{mg} / \mathrm{mL}$ and $2.3 \mathrm{mg} / \mathrm{mL}$ respectively. GMM and GMMG exhibit mixed-inhibition and uncompetitive inhibition respectively against AChE. GMMG possesses neuroprotective compounds such as cynerine $A$, graveolinine, militarinone $A$, eplerenone and curumenol. These findings showed a promising insight of G. manilaensis to be served as a nutraceutical for neuronal health care in the future.
\end{abstract}

Keywords: Gracilaria manilaensis, Alzheimer's disease, Graveolinine, Mixed-inhibition, Uncompetitive inhibition, Cholinesterases

Received: Oct 6, 2021 Revised: Nov 22, 2021 Accepted: Dec 12, 2021

${ }^{*}$ Corresponding author: Yoon-Yen Yow

Department of Biological Sciences, School of Medical and Life Sciences, Sunway University, Bandar Sunway, 47500 Selangor Darul Ehsan, Malaysia Tel: +603-7491-8622, E-mail: yoonyeny@sunway.edu.my

This is an Open Access article distributed under the terms of the Creative Commons Attribution Non-Commercial License (http://creativecommons.org/licenses/by$\mathrm{nc} / 4.0 /$ ) which permits unrestricted non-commercial use, distribution, and reproduction in any medium, provided the original work is properly cited.

Copyright $\odot 2022$ The Korean Society of Fisheries and Aquatic Science 


\section{Introduction}

Acetylcholine (ACh) is the major neurotransmitter synthesized from acetyl CoA and choline, by choline acetyltransferase (ChAT) in the cytoplasm (Ferreira-Vieira et al., 2016). It is uptaken by the vesicular acetylcholine transporter (VAChT) into the synaptic vesicles to convey a synaptic signal to the postsynaptic neurons through its binding to nicotinic ACh receptors (nAChR) or muscarinic ACh receptors (mAChR) (Silverthorn et al., 2016). In the synaptic cleft, ACh is promptly hydrolyzed to acetate and choline through the catalysis of acetylcholinesterase (AChE) enzyme and recycled into the presynaptic neuron (Colovic et al., 2013). Alzheimer's disease damages the brain cells that produce or use ACh, thereby reducing the amount of neurotransmitters available to carry neurological signals; whereas the amount of ChAT, nAChR, and $\mathrm{mAChR}$ are also abnormally downregulated in Alzheimer's patients (Kihara \& Shimohama, 2004; Lombardo \& Maskos, 2015). Furthermore, the natural process of ACh metabolism facilitated by AChE further reduces the amount of $\mathrm{ACh}$ and weakens the transportation of electrical impulses in the cholinergic system (Hung \& Fu, 2017). This results in impairments in motor function, memory and attention in patients.

While there is currently no cure for Alzheimer's, clinicians have applied cholinesterases inhibitors (ChEIs) to prevent the hydrolysis of ACh by cholinesterases (ChEs) (Hung \& Fu, 2017). The drugs indirectly aid in maintaining the ACh level that is important for learning and memory, and compensating the loss of functioning brain cells; thus, they enhance the symptoms related to memory thinking, language, judgment and other cognitive processes (Alzheimer's Association Report, 2021). To date, three out of five U.S. Food and Drug Administration (FDA) approved symptomatic medications for Alzheimer's disease are ChEIs, namely Aricept (donepezil), Exelon (rivastigmine), and Razdyne (galantamine) (Alzheimer's Association Report, 2021). Certain ChEIs seems to offer other benefits, for example, galantamine appears to stimulate the release of ACh and improve the way certain message-receiving neurons respond to it (Alzheimer's Association Report, 2021); while rivastigmine is able to intensify the cholinergic activity by providing dual inhibition of $\mathrm{AChE}$ and butyrylcholinesterase (BuChE), which further extend its usage in subcortical vascular and Parkinson's disease dementia (Kandiah et al., 2017). Besides, Donepezil was reported with several beneficial impacts on behavioral and neuropsychiatric symptoms, such as hallucinations, distractibility, aberrant motor behavior and apathy (Tsuno, 2009). Despite a small degree of improvement, clinical trials of all ChEIs are overall showing enhanced memory and thinking compared to placebo, as well as delay or slow worsening of Alzheimer's disease symptoms in up to $40 \%$ of individuals who taken the medication (Mielke et al., 2012). Despite all the benefits above, ChEIs do not reverse Alzheimer's nor stop the underlying degeneration of nerve cells. In fact, there is still risk of side effects that are unavoidable such as nausea, vomiting, gastrointestinal bleeding, bronchospasm and skin patches (Ruangritchankul et al., 2021). Knowing that nearly 10 million dementia patients are increasing every year (World Health Organisation, 2021) and the effect of current drugs are still in a large space to be improved, growing demand of getting better ChEIs with greater effect and lower side effects are gradually catching up, which has led us to explore any possibilities from the novel resources such as marine algae.

Consumption of algae has been revealed to prevent neurodegeneration. Studies showed that a higher seaweed intake in the Japanese diet and other East Asia countries compared to the European countries poised a lower neurodegenerative disorder risk (Okubo et al., 2017; Pangestuti \& Kim, 2011). In Malaysia, red seaweed Gracilaria is commonly used in traditional dishes for the Malay natives along the east coast of Peninsular Malaysia as Kelantanese seaweed salad named 'Kerabu Sare'. Gracilaria species including Gracilaria changii, Gracilaria firma, and G. manilaensis Yamamoto \& Trono are potential agarophytic species that provide raw materials for agar production in the food industry and as a food source for shellfish and shrimp (Ng et al., 2017; Phang et al., 2019; Yow et al., 2013). Current findings on G. manilaensis showed that it possesses various bioactive compounds with potential therapeutic effects. This includes hexadecanoic acid and 2-hydroxymyristic acid that portray anticancer property, 1-(4'-methoxyphenyl)-3-(2,4,6-trihydroxyphenyl)-3-hydroxypropanone that portrays antioxidant property, as well as cholesteryl myristate that portrays antibacterial property (Andriani et al., 2016). G. manilaensis from Malaysia also possesses the neuritogenic effect and in vitro antioxidant activities (Pang et al., 2018). The proven neurological benefits have driven our interest to further investigate the anti-AChE activity of $G$. manilaensis and to determine the bioactive substance(s) that is responsible for this activity.

\section{Materials and Methods}

\section{Specimen collection and processing}

Fresh specimens of G. manilaensis were collected from Kuala Muda, Kedah. The specimens were washed with salt water to re- 
move sands, mud and impurities, followed by the final rinse in distilled water and later froze. The frozen specimens were then freeze dried (Labogene, Germany) and pulverised. G. manilaensis powder was kept at $-20^{\circ} \mathrm{C}$ prior to extracts preparation.

\section{G. manilaensis extracts preparation}

G. manilaensis extracts were prepared from the powder by maceration as described in Pang et al. (2018). Briefly, $1 \mathrm{~g}$ of seaweed powder was dissolved into hot boiling water, methanol and ethanol at the ratio of 1:50 (w/v) respectively. For hot aqueous extract (GMHW), the mixture was incubated in roller mixer for $30 \mathrm{~min}$ at room temperature. The mixture was centrifuged at $2,688 \times \mathrm{g}$ for $20 \mathrm{~min}$ at $4^{\circ} \mathrm{C}$. After that, the supernatant was frozen and concentrated with a vacuum concentrator (Labogene, Germany). The dried product, GMHW was stored at $-20^{\circ} \mathrm{C}$ until used. Meanwhile, for methanol and ethanol extracts (GMM and GME), the solvent-powder mixtures were incubated in an incubator shaker at $9 \times \mathrm{g}$ for $36-48 \mathrm{~h}$ at room temperature. The mixture was centrifuged at $2,688 \times \mathrm{g}$ for $20 \mathrm{~min}$ at $4^{\circ} \mathrm{C}$. Subsequently, the supernatants were further concentrated using a rotary evaporator and vacuum concentrator. Both extracts were stored at $-20^{\circ} \mathrm{C}$ until used.

\section{In vitro anti-cholinesterase assay}

Ellman assay was used to determine the $\mathrm{AChE}$ and $\mathrm{BuChE}$ activities using the method described by Yoon et al. (2009) with slight modification. Each reaction was scaled to $200 \mu \mathrm{L}$ reaction in a 96-well microplate. To prepare GMHW, distilled water was used as the vehicle. For GMM and the positive controls (eserine and isoxazole), $10 \%$ aqueous methanol was used as the vehicle. Meanwhile, 10\% aqueous ethanol was used to dissolve GME. Briefly, $20 \mu \mathrm{L}$ of the sample was added into $140 \mu \mathrm{L}$ of sodium phosphate buffer ( $\mathrm{pH} 8.0)$ and $20 \mu \mathrm{L}$ of AChE $(0.036 \mathrm{U} / \mathrm{mL}$, C2888, Sigma-Aldrich, St. Louis, MO, USA) or BuChE (0.036 $\mathrm{U} / \mathrm{mL}$, C1057, Sigma-Aldrich). After $15 \mathrm{~min}$ of incubation, 20 $\mu \mathrm{L}$ of substrate $\mathrm{ACh}$ or BuCh (3 mM, Sigma-Aldrich) and $20 \mu \mathrm{L}$ of 5-5'-thiobis-2-nitrobenzoic acid (DTNB, $5 \mathrm{mM}$, Sigma-Aldrich) were added into the reaction mixture. The absorbance of each reaction mixture was read at $412 \mathrm{~nm}$ at $37^{\circ} \mathrm{C}$ by the kinetic loop of $3 \mathrm{~min}$ intervals for $15 \mathrm{~min}$. The rate of reaction was obtained by the slope of absorbance against the time in minutes. The unit was expressed in absorbance/min. The AChE or BuChE inhibitory activity (\%) was obtained by the formula:

AChE or BuChE inhibitory activity \%

$$
=\left(1-\frac{\text { Rate of reaction of samples }}{\text { Rate of reaction of the negative control }}\right) \times 100 \%
$$

The half-maximum effective concentration $\left(\mathrm{EC}_{50}\right)$ values of the positive controls and the extracts were measured by adapting from the dose-depending relationship curve of AChE or BuChE activity \% against the concentration of respective treatment. Three independent experiments were carried out to obtain the data in mean \pm SD.

\section{Enzyme kinetic study}

Enzyme kinetic study was also carried out using the method described by Yoon et al. (2009) with slight modification. The concentrations of GMM and GMMG were fixed at their respective $\mathrm{EC}_{25}$ or $\mathrm{EC}_{50}$. Substrates of ascending concentration from 3 , $6,9,12$, and $15 \mathrm{mM}$ were added after $15 \mathrm{~min}$ of incubation. The reciprocal value of the rate of reaction $(1 / \mathrm{V})$ and the reciprocal value of the substrate concentration $(1 /[\mathrm{S}] \mathrm{mM})$ was used to plot the line-weaver Burk plot. The values of enzyme activity $\left(K_{m}\right.$, $\mathrm{mM}$ ), the maximum rate of reaction ( $V_{\max }$, Absorbance/min) and inhibition constant $\left(K_{i}, \mathrm{mg} / \mathrm{mM}\right)$ were obtained by three independent experiments. These experiments were repeated for its quarter-maximum $\mathrm{EC}_{25}$.

\section{Isolation of active fractions}

GMM was selected as the most potent extract to be further investigated in this study. To produce fractions, $200 \mathrm{~g}$ powder was extracted with $2 \mathrm{~L}$ of absolute methanol for five times. After the removal of powder by filtration, approximate $10 \mathrm{~g}$ of GMM was concentrated with a rotary evaporator, and then dissolved in absolute chloroform. The GMM (10 g) was subjected to column chromatography over silica gel 60 , elution successively with hexane-chloroform (4:6-1:9), chloroform, chloroform-methanol (99:1-90:1) and ethanol to produce 10 main fractions based on thin-layer chromatography (TLC) profile: GMMA (75.1 mg), GMMB (46.6 mg), GMMC (41.9 mg), GMMD (129.6 mg), GMME (97.6 mg), GMMF (283.4 mg), GMMG (272.6 mg), GMMH (85.6 mg), GMMI (339.2 mg), and GMMJ (1,227.3 mg).

\section{Liquid chromatography-mass spectrometry (LCMS) analysis}

GMMG was subjected to LCMS analysis with Agilent 1290 Infinity LC system coupled to Agilent 6520 Accurate-Mass Q-TOF mass spectrometer with dual ESI source (Agilent Technologies, Santa Clara, CA, USA). The column used was Agilent 
Zorbax Eclipse XDB-C18, Narrow-Bore $2.1 \times 150 \mathrm{~mm}, 3.5$ micron (P/N: 930990-902) with mobile phase $0.1 \%$ formic acid in water and $0.1 \%$ formic acid in acetonitrile. $1 \mu \mathrm{L}$ of sample $(1$ $\mathrm{mg} / \mathrm{mL}$ ) was injected at the flow rate of $0.5 \mathrm{~mL} / \mathrm{min}$. The result of chromatogram data was analysed with Agilent MassHunter Qualitative Analysis B.07.00 (Method: Metabolomic-2019.m) matched with Metiln database based on mass over charge $(\mathrm{m} / \mathrm{z})$. Compounds were shortlisted by elimination of blank, include all the compounds with Score Db or Score MFG $\geq 90$, and with Difference (Db.ppm) or Difference (MFG.ppm) that is \pm 5 . Activities of the known compound were matched with publication and database on Web of Science and PubChem.

\section{Statistical analysis}

The means of data were subjected to one-way analysis of variance (ANOVA). Dunnett and Tukey Post Hoc were implemented to test for the significant difference between extracts. All the analysis was done by Graph Pad Prism ver. 7.

\section{Results}

\section{ChEs inhibitory activities of G. manilaensis}

All G. manilaensis extracts possessed anti-AChE activity in majority of the tested concentrations (Fig. 1). Meanwhile, none of the extracts but isoxazole showed significant anti-BuChE activ-
Isoxazole

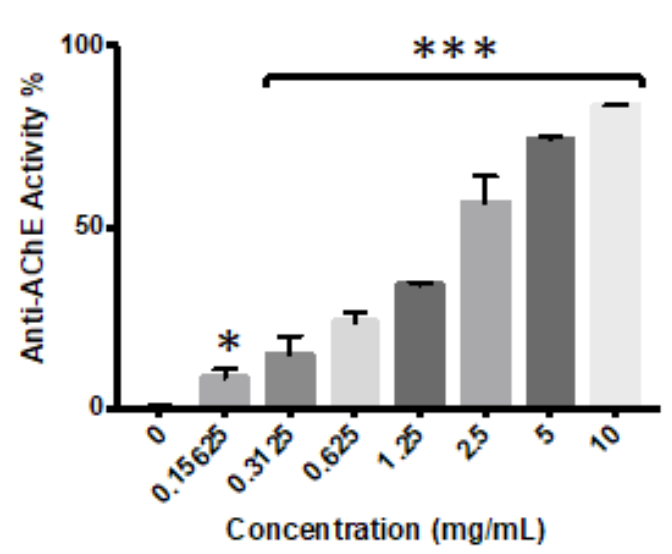

GMM

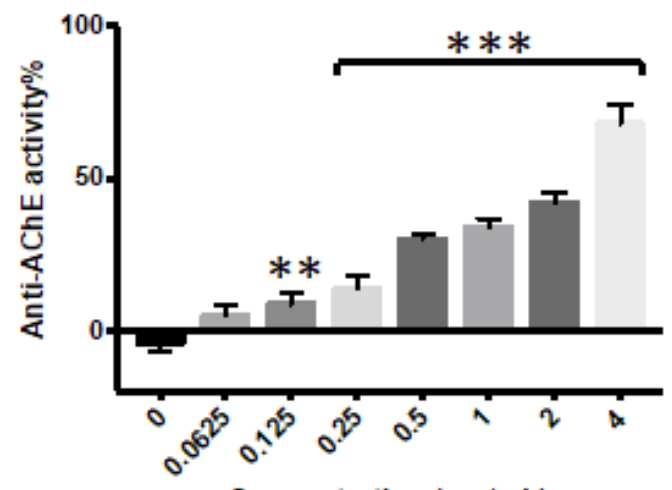

Concentration $(\mathrm{mg} / \mathrm{mL})$
GMHW

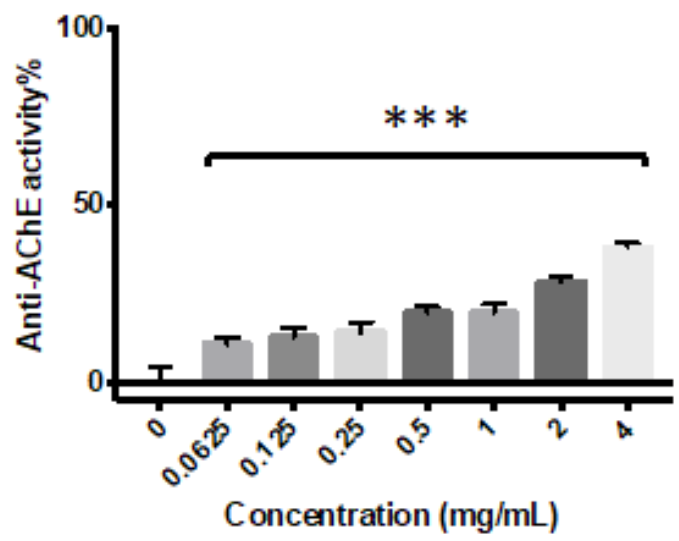

GME

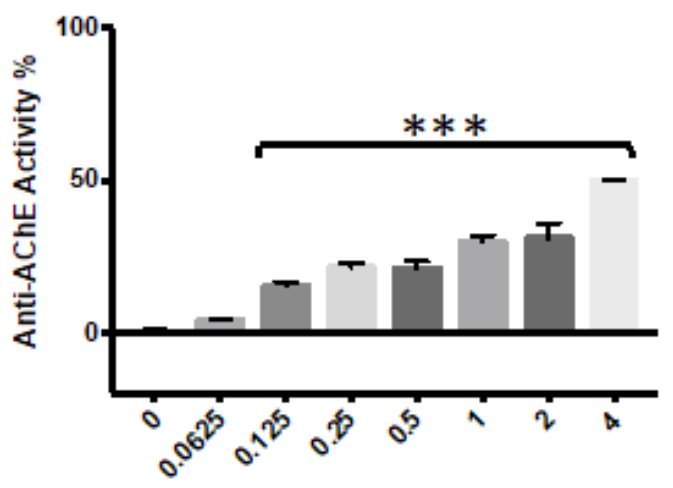

Concentration $(\mathrm{mg} / \mathrm{mL})$

Fig. 1. AChE inhibition activity of Gracilaria manilaensis extracts and the positive controls. Data are expressed in mean \pm SD $(\mathrm{n}=3)$. ${ }^{*}$ Arterisk symbol indicates significant differences $(0 \mathrm{mg} / \mathrm{mL})\left({ }^{*} p<0.05,{ }^{* *} p<0.01,{ }^{* * *} p<0.005\right.$; Dunnett $)$ against the negative control. Isoxazole was used as the positive control. AChE, acetylcholinesterase; GMHW, hot water extract; GMM, methanol extract; GME, ethanol extract. 
ity $(p<0.05)$ (Fig. 2). GMHW produced significant anti-AChE activity of $10.98 \pm 1.67 \%$ at concentration as low as $0.0625 \mathrm{mg} /$ $\mathrm{mL}(p<0.005)$. The highest activity of GMHW observed was $38.23 \pm 1.05 \%$ at $4 \mathrm{mg} / \mathrm{mL}$. On the other hand, GMM and GME only showed significant anti-AChE activity at $0.125 \mathrm{mg} / \mathrm{mL}$, with $8.62 \pm 3.73 \%$ and $15.21 \pm 1.28 \%$ respectively $(p<0.01$ and $p<0.005)$. However, anti-AChE activity of GMM and GME observed a rapid increment from $2 \mathrm{mg} / \mathrm{mL}$ to $4 \mathrm{mg} / \mathrm{mL}$, which resulted in a higher anti-AChE activity of $69.3 \pm 7.16 \%$ and 49.94 $\pm 0.23 \%$ at $4 \mathrm{mg} / \mathrm{mL}$ respectively. Since GMM was the only extract that showed anti-AChE activity higher than $50 \%$ at $4 \mathrm{mg} /$ $\mathrm{mL}$, it was selected for the downstream fractionation process.
GMM was fractionated into 10 fractions according to the TLC profile (Fig. 3). All fractions except GMMD possessed significant anti-AChE activity $(p<0.05)$ against the negative control (Fig. 4). GMMA and GMME showed the lowest anti-AChE activity at $33.8 \pm 4.6 \%$ and $37.1 \pm 3.8 \%$ respectively. Meanwhile, GMMF, GMMH, and GMMJ showed moderate activity at $43.4 \pm 7.7 \%, 45.3 \pm 1.5 \%$ and $41.7 \pm 1.9 \%$ respectively. Furthermore, GMMB, GMMC, and GMMI showed moderate-high anti-AChE activity at $54.4 \pm 4.8 \%, 62.0 \pm 1.1$ and $53.6 \pm 1.5 \%$ respectively. GMMG showed the highest anti-AChE activity at $69.2 \pm 5.1 \%$; thus, GMMG was selected for subsequent assay of cholinesterase inhibitory activities.
Isoxazole

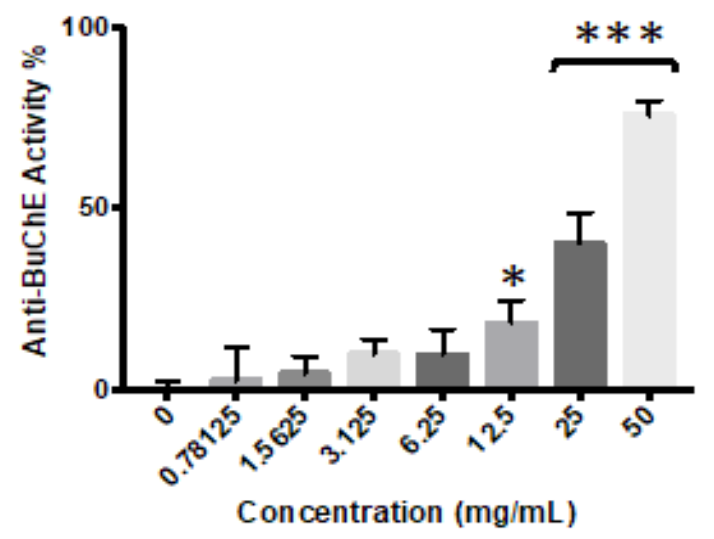

GMM

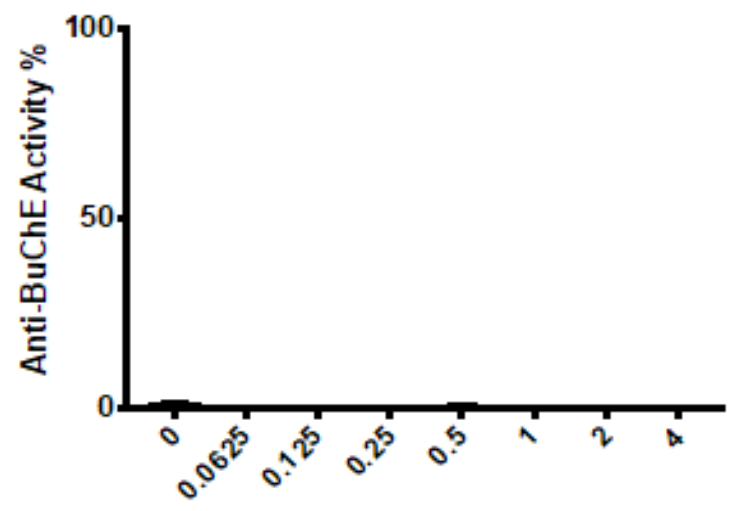

Concentration $(\mathrm{mg} / \mathrm{mL})$
GMHW

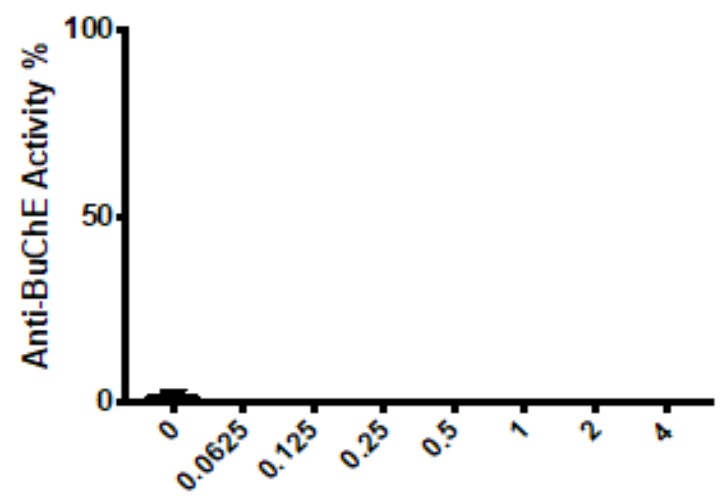

Concentration $(\mathrm{mg} / \mathrm{mL})$

GME

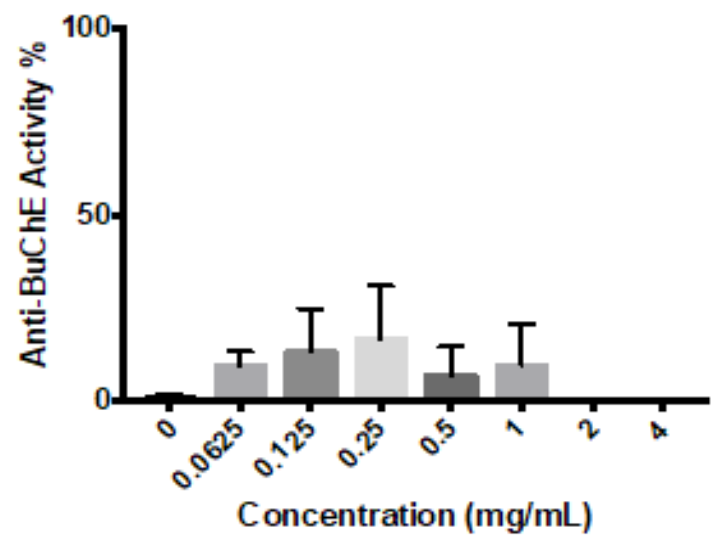

Fig. 2. BuChE inhibition activity of Gracilaria manilaensis extracts and the positive controls. Data are expressed in mean \pm SD $(\mathrm{n}=3)$. ${ }^{*}$ Arterisk symbol indicates significant difference $(0 \mathrm{mg} / \mathrm{mL})\left({ }^{*} p<0.05,{ }^{* *} p<0.01,{ }^{* * *} p<0.005\right.$; Dunnett) against the negative control. Isoxazole was used as the positive control. BuChE, butyrylcholinesterase; GMHW, hot water extract; GMM, methanol extract; GME, ethanol extract. 


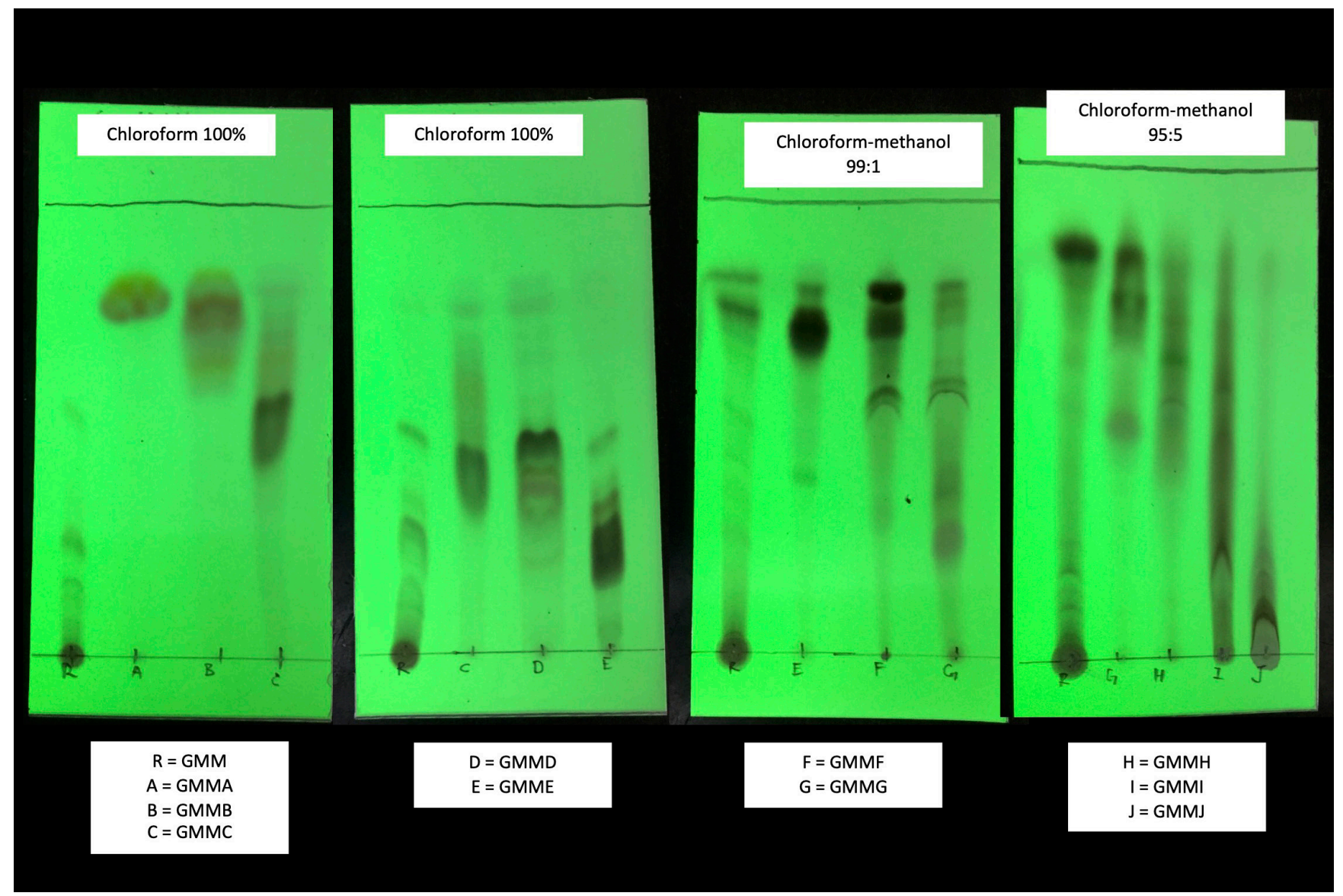

Fig. 3. Thin layer chromatography (TLC) profile of Gracilaria manilaensis methanol fraction GMMA to GMMJ. Each TLC plate from left to right was separated with different ratio of chloroform-methanol solvent system as labeled. GMM was used as the reference, marked as R in every TLC plate. GMM, methanol extract; GMMA-J, fraction A to J.

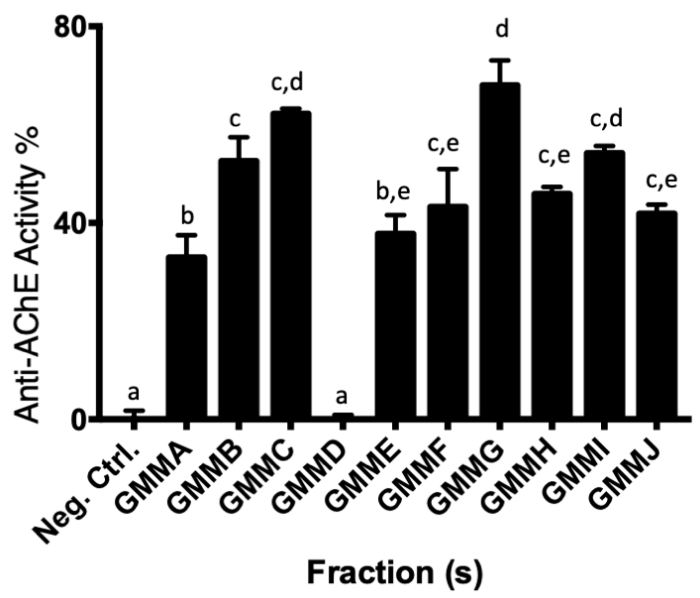

Fig. 4. AChE inhibition activity of 10 methanol fractions of Gracilaria manilaensis (GMMA to GMMJ) at $30 \mathrm{mg} / \mathrm{mL}$ with $10 \%$ aqueous methanol as the negative controls. Data are expressed as the mean $\pm S D(n=3)$. Different alphabets indicated significant different to other data ( $p<0.05$; Tukey). AChE, acetylcholinesterase; GMMA-J, fraction A to J. 
GMMG showed positive AChE activity but negative BuChE activity (Fig. 5), similar to its predecessor, GMM. At the concentration of $0.375 \mathrm{mg} / \mathrm{mL}$, GMMG started to show significant anti-AChE activity with $20.89 \pm 0.27 \%$. The anti-AChE activity of GMMG increased with the concentration, where it reached the highest at $3 \mathrm{mg} / \mathrm{mL}$ with $61.09 \pm 6.15 \%$.

Anti-AChE and BuChE activities of G. manilaensis and the positive controls (eserine and isoxazole) expressed in $\mathrm{EC}_{50}$ (Table 1). In this study, eserine and isoxazole were used as the positive control. Eserine has been optimised in vitro in the Ellman assay as described in Yoon et al. (2008, 2009), whereby isoxazole is a novel AChE inhibitor described in Gutiérrez et al. (2013) which is effective against AChE from Electroporus electricus, the similar AChE used in our study model (C2888, Sigma-Aldrich). Notable, eserine showed the lowest $\mathrm{EC}_{50}$ at $10.6 \pm 2.0 \mathrm{ng} / \mathrm{mL}$, whereas GMM and GMMG showed anti-AChE activity with
$\mathrm{EC}_{50}$ at $2.60 \pm 0.16 \mathrm{mg} / \mathrm{mL}$ and $2.22 \pm 0.27 \mathrm{mg} / \mathrm{mL}$ respectively, significantly lower than isoxazole and GME $(p<0.05)$. For Bu$\mathrm{ChE}$, all samples were negative within the tested range, hence no $\mathrm{EC}_{50}$ value was shown. Based on Andriani et al. (2016), methanol was the best solvent to extract the anti-AChE compound(s) from G. manilaensis, which was similar to our findings. GMM and GMMG warrant a high potential for further testing.

\section{AChE inhibitory kinetic of GMM and GMMG}

GMM and GMMG were tested for their enzyme inhibition kinetic using the Lineweaver-Burk plot (Figs. 6 and 7). The presence of GMM increased the value of $K_{m}$ from $1.48 \mathrm{mM}$ to 1.68 $\mathrm{mM}$ at $\mathrm{EC}_{25}(1.3 \mathrm{mg} / \mathrm{mL})$ and $2.03 \mathrm{mM}$ at $\mathrm{EC}_{50}(2.6 \mathrm{mg} / \mathrm{mL})$. However, the value of $V_{\max }$ was decreased from $0.0281 \mathrm{mM}$ to $0.0231 \mathrm{mM}$ at $\mathrm{EC}_{25}(1.3 \mathrm{mg} / \mathrm{mL})$ and $0.0213 \mathrm{mM}$ at $\mathrm{EC}_{50}(2.6$ $\mathrm{mg} / \mathrm{mL}$ ) by GMM (Table 2 ). This matched the mixed-inhibition
Eserine
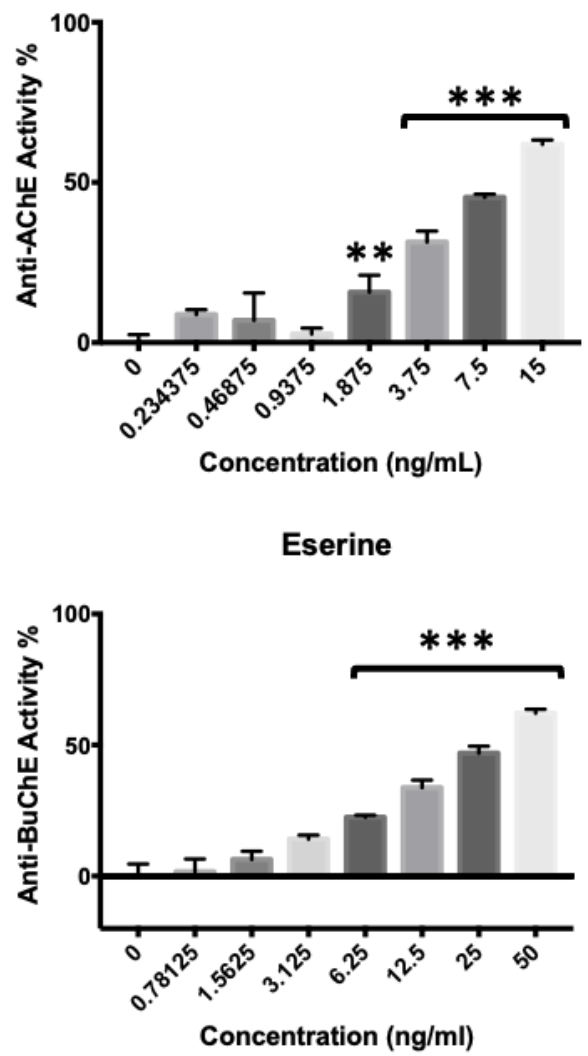

GMMG
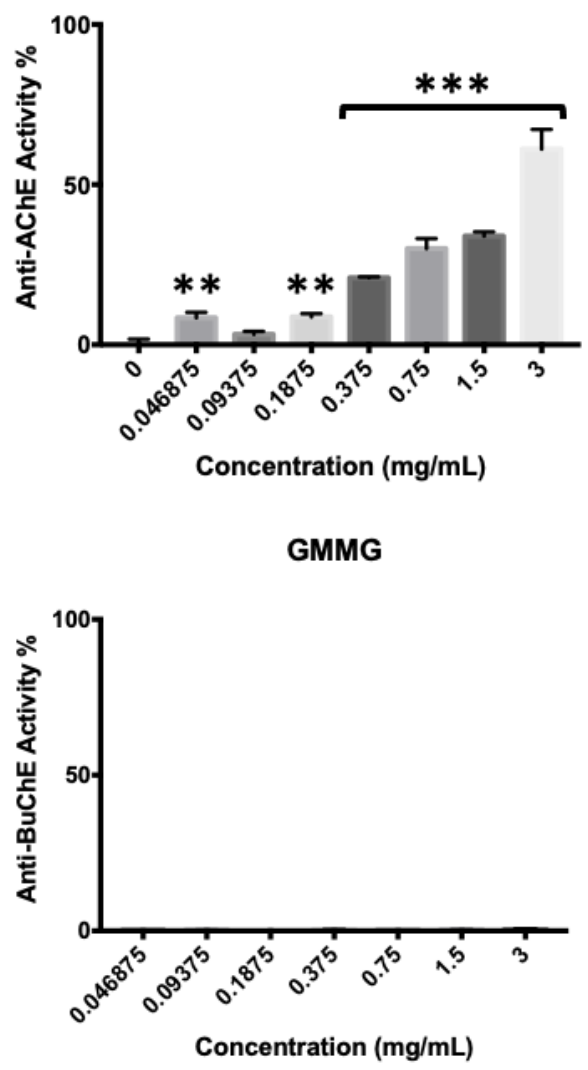

Fig. 5. AChE and BuChE inhibition activities of GMMG and the positive controls. Data are expressed in mean \pm SD $(n=3)$. *Arterisk indicates significant $(0 \mathrm{mg} / \mathrm{mL})\left({ }^{*} p<0.05,{ }^{* *} p<0.01,{ }^{* * *} p<0.005\right.$; Dunnett) differences against the negative control. Eserine was used as the positive control. AChE, acetylcholinesterase; GMMG, fraction G; BuChE, butyrylcholinesterase. 
Table 1. Anti-AChE and BuChE activities of GMHW, GMM, GME, GMMG and the positive controls in $\mathrm{EC}_{50}(\mathrm{mg} / \mathrm{mL})$

\begin{tabular}{lll}
\hline Samples & \multicolumn{2}{c}{$\mathrm{EC}_{50}(\mathrm{mg} / \mathrm{mL})$} \\
\cline { 2 - 3 } & Anti-AChE activity & Anti-BuChE activity \\
\hline ssoxazole $^{*}$ & $4.10 \pm 0.23^{\mathrm{a}}$ & $32.47 \pm 3.35^{\mathrm{a}}$ \\
Eserine $^{*}$ & $1.06 \times 10^{-5} \pm 2.00 \times 10^{-7 \mathrm{~b}}$ & $3.41 \times 10^{-5} \pm 1.20 \times 10^{-6 \mathrm{~b}}$ \\
GMHW & Negative & Negative \\
GMM & $2.60 \pm 0.16^{\mathrm{d}}$ & Negative \\
GME & $3.77 \pm 0.20^{\mathrm{a}}$ & Negative \\
GMMG & $2.30 \pm 0.18^{\mathrm{d}}$ & Negative \\
\hline
\end{tabular}

Data are expressed as mean $\pm S D(n=3)$.

${ }^{\text {a-d }}$ Mean with different alphabet within the same column indicate significant differences ( $p$ $<0.05$; Tukey).

*Asterisk symbol indicates the positive controls.

AChE, acetylcholinesterase; BuChE, butyrylcholinesterase; GMHW, hot water extract; GMM, methanol extract; GME, ethanol extract; GMMG, fraction G.

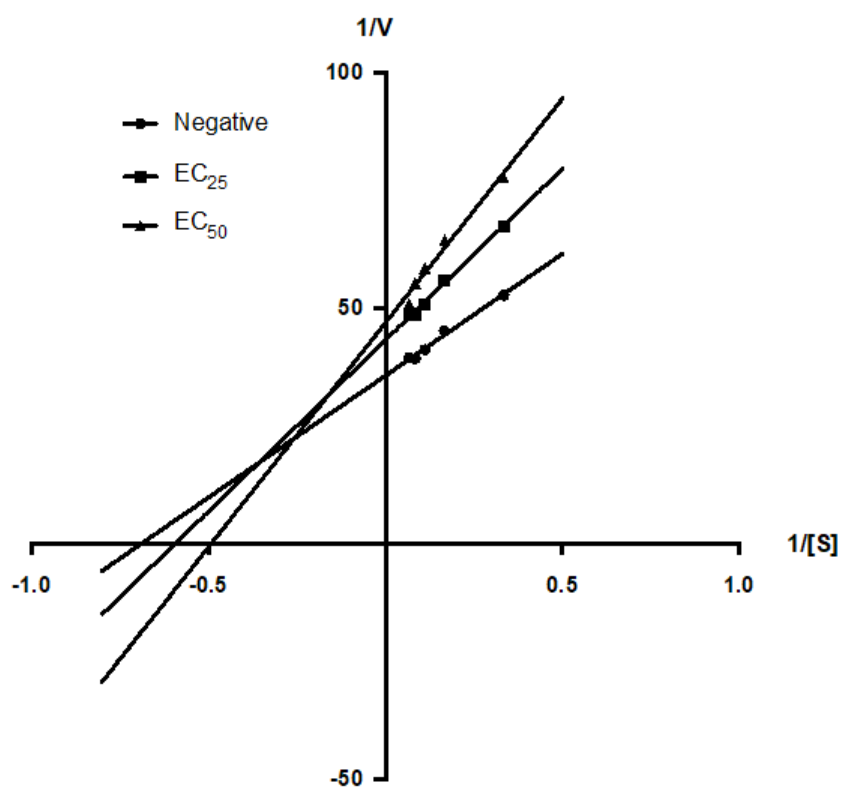

Fig. 6. Line-weaver Burk plot of AChE activity in the presence of GMM. AChE, acetylcholinesterase; GMM, methanol extract.

pattern of the Lineweaver-Burk plot, suggested that the GMM might possess bioactive compound(s) which can bind with both the enzyme and enzyme-substrate complex, with a higher affinity to the enzyme. GMM could be a mixed inhibitor to the anti-AChE activity.

On the other hand, GMMG decreased the value of $K_{m}$ from $1.78 \mathrm{mM}$ to $1.55 \mathrm{mM}$ at $\mathrm{EC}_{25}(1.15 \mathrm{mg} / \mathrm{mL})$ and $1.33 \mathrm{mM}$ at $\mathrm{EC}_{50}(2.30 \mathrm{mg} / \mathrm{mL})$. The value of $V_{\max }$ was decreased from 0.026 $\mathrm{mM}$ to $0.02 \mathrm{mM}$ at $\mathrm{EC}_{25}(1.15 \mathrm{mg} / \mathrm{mL})$ and $0.016 \mathrm{mM}$ at $\mathrm{EC}_{50}$

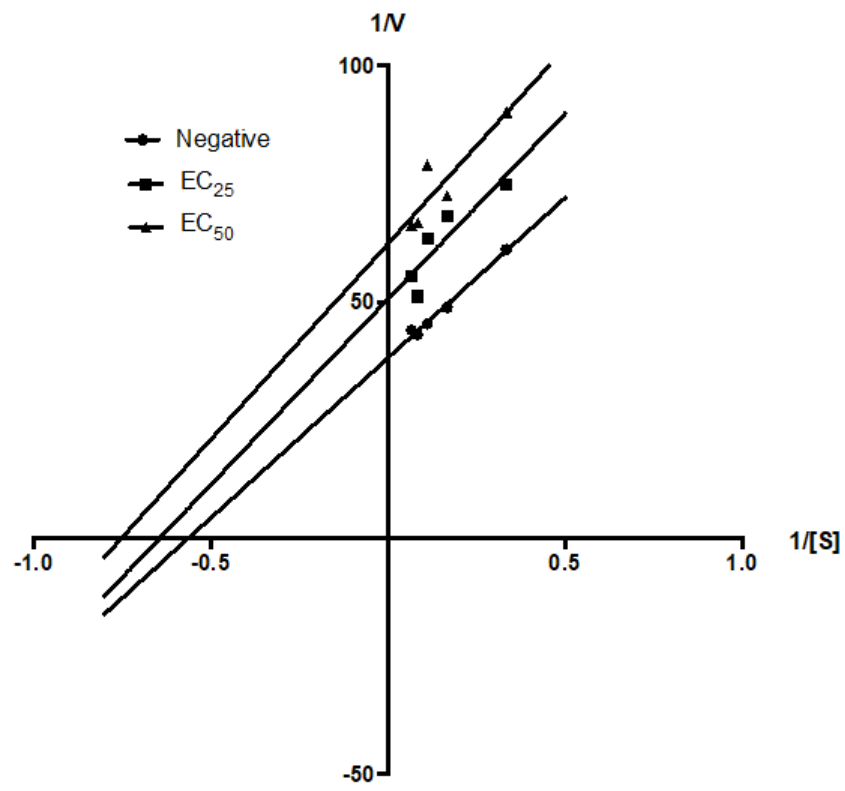

Fig. 7. Line-weaver Burk plot of AChE activity in the presence of GMMG isolated from methanol extract. $A C h E$, acetylcholinesterase; GMMG, fraction $\mathrm{G}$.

Table 2. The kinetic parameter of AChE activity in the presence of GMM

\begin{tabular}{llll}
\hline Inhibitors & $K_{m}(\mathrm{mM})$ & $V_{\max }(\mathrm{mM})$ & $K_{i}$ \\
\hline Without inhibitor & 1.48 & 0.028 & \\
$\mathrm{EC}_{25}(1.3 \mathrm{mg} / \mathrm{mL})$ & 1.68 & 0.023 & 3.36 \\
$\mathrm{EC}_{50}(2.6 \mathrm{mg} / \mathrm{mL})$ & 2.03 & 0.021 & 3.18 \\
\hline
\end{tabular}

AChE, acetylcholinesterase; GMM, methanol extract.

$(2.30 \mathrm{mg} / \mathrm{mL}$ ) by GMMG (Table 3). This matched the uncompetitive inhibition pattern of the Lineweaver-Burk plot, suggested that the GMMG possess bioactive compound(s) which can bind with the enzyme-substrate complex specifically. GMMG could be an uncompetitive inhibitor to the anti-AChE activity.

\section{Identification of compound(s) in GMMG}

LCMS analysis was carried out and the results detected 136 peaks in the positive ion mass spectra. Of these, 28 peaks were matched with the identity of known molecules on the Metlin database, with Molecular Formula Generator (MFG) scores above $90 \%$ and \pm 5 differences in MFG scores. The proposed compounds were searched and presented in Table 4. Interestingly, cynerine A, graveolinine, militarinone A, eplerenone and curumenol are the neuroprotective-related compounds 
Table 3. The kinetic parameter of AChE activity in the presence of GMMG

\begin{tabular}{llll}
\hline Inhibitor & $K_{m}(\mathrm{mM})$ & $V_{\max }(\mathrm{mM})$ & $K_{i}$ \\
\hline Without inhibitor & 1.78 & 0.026 & \\
$\mathrm{EC}_{25}(1.15 \mathrm{mg} / \mathrm{mL})$ & 1.55 & 0.020 & 7.21 \\
$\mathrm{EC}_{50}(2.30 \mathrm{mg} / \mathrm{mL})$ & 1.33 & 0.016 & 10.32 \\
\hline
\end{tabular}

AChE, acetylcholinesterase; GMMG, fraction G. detected among the 28 known compounds. In contrast, 10 other compounds that had MFG scores above the cut-off did not match with any molecules in the library, indicating a large family of new unknown compounds that are yet to be explored in GMMG (Table 5). The chromatograms and MS spectra of compounds were shown in Figs. 3 and 8.

Table 4. Identified compounds in GMMG fraction through LCMS analysis

\begin{tabular}{|c|c|c|c|c|c|c|c|c|}
\hline No & Name & Formula & $\mathrm{m} / \mathrm{z}$ & Mass & Group & Activity & $\begin{array}{l}\text { Related com- } \\
\text { pound(s) }\end{array}$ & Activity \\
\hline 1 & $\begin{array}{l}\text { 4-(2-hydroxyprop- } \\
\text { oxy)-3,5-dimeth- } \\
\text { yl-phenol }\end{array}$ & $\mathrm{C}_{11} \mathrm{H}_{16} \mathrm{O}_{3}$ & 197.12 & 196.11 & Alcohol & - No record & & \\
\hline 2 & Dioscoretine & $\mathrm{C}_{13} \mathrm{H}_{23} \mathrm{NO}_{3}$ & 242.17 & 241.17 & Fatty acid & - No record & & \\
\hline 3 & $\begin{array}{l}\text { 2-Phenylethyl 3-methyl- } \\
\text { butanoate }\end{array}$ & $\mathrm{C}_{13} \mathrm{H}_{18} \mathrm{O}_{2}$ & 207.14 & 206.13 & Carboxylic acid & - No record & & \\
\hline 4 & ML-236C & $\mathrm{C}_{18} \mathrm{H}_{26} \mathrm{O}_{3}$ & 291.20 & 290.19 & Carbobicylic compound & $\begin{array}{l}\text { - Anticholesteremic (Endo } \\
\text { et al., 1976) }\end{array}$ & & \\
\hline 5 & C16 Sphinganine & $\mathrm{C}_{16} \mathrm{H}_{35} \mathrm{NO}_{2}$ & 274.27 & 273.27 & Lipid:Phospholipid & $\begin{array}{l}\text { - Antibacteria (Reid et al., } \\
\text { 2019) } \\
\text { - Anticancer (Bagheri et al., } \\
\text { 2018) }\end{array}$ & & \\
\hline 6 & 2,6-Nonadien-1-ol & $\mathrm{C}_{9} \mathrm{H}_{16} \mathrm{O}$ & 158.15 & 140.12 & Fatty alcohol & $\begin{array}{l}\text { - Flavour compound (Kemp } \\
\text { et al., 1974; Flath et al., } \\
\text { 1983; McGinty et al., 2010; } \\
\text { Api et al., 2015, 2019) }\end{array}$ & & \\
\hline 7 & (-)-trans-C75 & $\mathrm{C}_{14} \mathrm{H}_{22} \mathrm{O}_{4}$ & 272.19 & 254.15 & Carboxylic acid & - No record & & \\
\hline 8 & Cyrneine $A^{*}$ & $\mathrm{C}_{20} \mathrm{H}_{28} \mathrm{O}_{3}$ & 317.21 & 316.20 & Terpene: Diterpene & $\begin{array}{l}\text { - Neurite outgrowth (Mar- } \\
\text { cotullio et al., 2006; Obara } \\
\text { et al., 2007) }\end{array}$ & $\begin{array}{l}\text { Cyathane diterpene } \\
\text { group }\end{array}$ & $\begin{array}{l}\text { - Anti-oxidant } \\
\text { (Marcotullio et al., } \\
\text { 2008) } \\
\text { - Anti-nitric oxide } \\
\text { (Wang et al., } \\
\text { 2014) } \\
\text { - Neurite out- } \\
\text { growth (Cao et } \\
\text { al., 2018) } \\
\text { - Anti-bacterial } \\
\text { (Nitthithanasilp } \\
\text { et al., 2018) }\end{array}$ \\
\hline 9 & 7beta-Hydroxy-lathyrol & $\mathrm{C}_{20} \mathrm{H}_{30} \mathrm{O}_{4}$ & 335.22 & 334.21 & Lipid: Diterpene & - No record & & \\
\hline 10 & Graveolinine* & $\mathrm{C}_{17} \mathrm{H}_{13} \mathrm{NO}_{3}$ & 297.12 & 279.09 & Quinonline & $\begin{array}{l}\text { Anti-angiogenesis (An et al., } \\
\text { 2010) } \\
\text { Anti-tumor and anti-platelet } \\
\text { aggregation (Wu et al., } \\
\text { 2003) } \\
\text { Anti-AChE and anti- } \beta \text { amyloid } \\
\text { (Luo et al., 2020) }\end{array}$ & & \\
\hline 11 & $\begin{array}{l}\text { 3a-Hydroxy-4,4-bis- } \\
\text { nor-8,11,13-podocar- } \\
\text { patriene }\end{array}$ & $\mathrm{C}_{15} \mathrm{H}_{20} \mathrm{O}$ & 217.16 & 216.15 & Phenol & - No record & & \\
\hline 12 & Militarinone $\mathrm{A}^{*}$ & $\mathrm{C}_{26} \mathrm{H}_{37} \mathrm{NO}_{6}$ & 460.27 & 459.26 & Pyridine alkaloid & $\begin{array}{l}\text { - Neurite outgrowth } \\
\text { (Schmidt et al., 2002; Riese } \\
\text { et al., 2004; Küenzi et al., } \\
\text { 2008) }\end{array}$ & $\begin{array}{l}\text { 4-hydroxy-2-pyri- } \\
\text { done } \\
\text { (+)-N-Deoxymilitari- } \\
\text { none A }\end{array}$ & $\begin{array}{l}\text { - Neurite out- } \\
\text { growth (Schröder } \\
\text { et al., 2015) } \\
\text { - Neurite out- } \\
\text { growth (Cheng et } \\
\text { al., 2006) }\end{array}$ \\
\hline
\end{tabular}


Table 4. Continued

\begin{tabular}{|c|c|c|c|c|c|c|c|c|}
\hline No & Name & Formula & $\mathrm{m} / \mathrm{z}$ & Mass & Group & Activity & $\begin{array}{l}\text { Related com- } \\
\text { pound(s) }\end{array}$ & Activity \\
\hline 13 & Eplerenone $^{*}$ & $\mathrm{C}_{24} \mathrm{H}_{30} \mathrm{O}_{6}$ & 432.24 & 414.21 & Lactone & $\begin{array}{l}\text { - Anti-inflammation (Suzuki } \\
\text { et al., 2006; Xiao et al., } \\
\text { 2009; Bayorh et al., 2012; } \\
\text { Chen et al., 2013, 2018; } \\
\text { Łabuzek et al., 2014; Wada } \\
\text { et al., 2017; Vecchiola et al., } \\
\text { 2020) } \\
\text { - Neuroprotective (Dong et } \\
\text { al., 2012; Wang et al., 2020) }\end{array}$ & & \\
\hline 14 & Curcumenol $^{*}$ & $\mathrm{C}_{15} \mathrm{H}_{22} \mathrm{O}_{2}$ & 235.17 & 234.16 & Curcumin & $\begin{array}{l}\text { - Anti-neuroinflammation } \\
\text { (Tanaka et al., 2008; Lo et } \\
\text { al., 2015; Hsiao et al., 2020; } \\
\text { Pintatum et al., 2020) } \\
\text { - Antioxidant } \\
\text { - } \text { Neuroprotective (Hamdi } \\
\text { et al., 2015) }\end{array}$ & Oxycurcuminol & $\begin{array}{l}\text { - Anti-stroke (Chen } \\
\text { et al., 2018) }\end{array}$ \\
\hline 15 & $\begin{array}{l}\text { (+-)-Trihydroxy-decipia- } \\
\text { diene }\end{array}$ & $\mathrm{C}_{20} \mathrm{H}_{32} \mathrm{O}_{3}$ & 321.24 & 320.23 & Lipid: Isoprenoid & - No record & & \\
\hline 16 & $\begin{array}{l}\text { alhpa-Tocopheronolac- } \\
\text { tone }\end{array}$ & $\mathrm{C}_{16} \mathrm{H}_{22} \mathrm{O}_{4}$ & 301.14 & 278.15 & Lipid: Isoprenoid & - No record & & \\
\hline 17 & $\begin{array}{l}\text { N-cis-Tetra- } \\
\text { dec-9Z-enoyl-L-Ho- } \\
\text { moserine lactone }\end{array}$ & $\mathrm{C}_{18} \mathrm{H}_{31} \mathrm{NO}_{3}$ & 310.24 & 309.23 & Lactone & - No record & & \\
\hline 18 & Stigmatellin $Y$ & $\mathrm{C}_{29} \mathrm{H}_{40} \mathrm{O}_{6}$ & 502.32 & 484.28 & Phenol & - No record & & \\
\hline 19 & Anandamide (20:I, n-9) & $\mathrm{C}_{22} \mathrm{H}_{43} \mathrm{NO}_{2}$ & 376.32 & 353.33 & Fatty amide & - No record & & \\
\hline 20 & $\begin{array}{l}\text { 2-Amino-14,16-dimeth- } \\
\text { yloctadecan-3-ol }\end{array}$ & $\mathrm{C}_{20} \mathrm{H}_{43} \mathrm{NO}$ & 336.32 & 313.33 & Amino alcohol & - No record & & \\
\hline 21 & 2-Ethyl-dodecanoic acid & $\mathrm{C}_{14} \mathrm{H}_{28} \mathrm{O}_{2}$ & 229.22 & 228.21 & Fatty acid & - No record & & \\
\hline 22 & (-)-Isoamijiol & $\mathrm{C}_{20} \mathrm{H}_{32} \mathrm{O}_{2}$ & 322.27 & 304.24 & Lipid: Isoprenoid & - No record & & \\
\hline 23 & Palmitic amide & $\mathrm{C}_{16} \mathrm{H}_{33} \mathrm{NO}$ & 256.26 & 255.26 & Fatty amide & - No record & & \\
\hline 24 & Coproporphyrin IV & $\mathrm{C}_{36} \mathrm{H}_{38} \mathrm{~N}_{4} \mathrm{O}_{8}$ & 655.28 & 654.27 & Porphyrin & - No record & & \\
\hline 25 & Cassaidine & $\mathrm{C}_{24} \mathrm{H}_{41} \mathrm{NO}_{4}$ & 408.31 & 407.30 & Tricylic diterpenoids & - No record & & \\
\hline 26 & Haplophytine & $\mathrm{C}_{37} \mathrm{H}_{40} \mathrm{~N}_{4} \mathrm{O}_{7}$ & 653.30 & 652.29 & Indole alkaloid & - No record & & \\
\hline 27 & 24,25-Epoxy-cholesterol & $\mathrm{C}_{27} \mathrm{H}_{44} \mathrm{O}_{2}$ & 401.34 & 400.33 & Desmosterol & - No record & & \\
\hline 28 & $\begin{array}{l}\text { MG- } \\
\qquad \text { DG(18:1(9Z)/18:1(9Z)) }\end{array}$ & $\mathrm{C}_{45} \mathrm{H}_{82} \mathrm{O}_{10}$ & 805.58 & 782.59 & Glycosyldiradylglycerols & - No record & & \\
\hline
\end{tabular}

Compound marked with asterisk symbol indicates compound with previously identified neuroprotective properties. GMMG, fraction G; LCMS, liquid chromatography-mass spectrometry; AChE, acetylcholinesterase.

\section{Discussion}

To date, there are many red algae with anti-AChE activity have been reported, including Hypnea valentiae (Suganthy et al., 2010), Gracilaria edulis (Suganthy et al., 2010), Gelidiella acerosa (Syad et al., 2012, 2016), Hypnea musciformis (Machado et al., 2015), Ochtodes secundiramea (Machado et al., 2015), Pterocladiella capillacea (Machado et al., 2015), Gelidium foliaceum (Kannan et al., 2013), Amphiroa beauvoisii (Kannan et al.,
2013), Laurencia complanate (Kannan et al., 2013), Rhodomelopsis africana (Kannan et al., 2013), Porphyra tenera (Senevirathne et al., 2010), G. changii (Andriani et al., 2016) and G. manilaensis (Andriani et al., 2016). In contrast, this is the first comprehensive study of Malaysian G. manilaensis whereby the anti-AChE and BuChE activities and their inhibition kinetic were reported. In the present study, GMM and GMMG possess anti-AChE activity closely compared to the ethanol extracts of $H$. valentiae and $G$. edulis, with $\mathrm{IC}_{50}$ of $2.6 \mathrm{mg} / \mathrm{mL}$ and $3.5 \mathrm{mg} / \mathrm{mL}$ 
Table 5. Unidentified compounds in GMMG

\begin{tabular}{lll}
\hline Formula & $\mathrm{m} / \mathrm{z}$ & mass \\
\hline $\mathrm{C}_{15} \mathrm{H}_{29} \mathrm{~N}_{5} \mathrm{O}_{4}$ & 344.2285 & 343.2213 \\
$\mathrm{C}_{20} \mathrm{H}_{37} \mathrm{~N}_{15} \mathrm{O}_{2}$ & 520.3326 & 519.3255 \\
$\mathrm{C}_{27} \mathrm{H}_{53} \mathrm{~N}_{5} \mathrm{O}_{10}$ & 608.3857 & 607.379 \\
$\mathrm{C}_{22} \mathrm{H}_{22} \mathrm{~N}_{6} \mathrm{O}_{4}$ & 435.1767 & 434.1696 \\
$\mathrm{C}_{21} \mathrm{H}_{29} \mathrm{~N}_{3} \mathrm{O}_{8}$ & 452.2022 & 451.1949 \\
$\mathrm{C}_{28} \mathrm{H}_{32} \mathrm{~N}_{2} \mathrm{O}_{3} \mathrm{~S}$ & 477.2227 & 476.2139 \\
$\mathrm{C}_{11} \mathrm{H}_{18} \mathrm{O}_{3}$ & 199.1329 & 198.1255 \\
$\mathrm{C}_{22} \mathrm{H}_{41} \mathrm{NO}_{2}$ & 352.3236 & 351.3139 \\
$\mathrm{C}_{31} \mathrm{H}_{36} \mathrm{~N}_{14} \mathrm{~S}$ & 654.3324 & 636.2978 \\
$\mathrm{C}_{37} \mathrm{H}_{34} \mathrm{~N}_{8} \mathrm{O}_{3}$ & 639.2822 & 638.2753
\end{tabular}

GMMG, fraction $\mathrm{G}$. may have a lower tendency to cause toxicity compared to other red algae according to Jońca et al. (2015). BuChE is also known as plasma cholinesterase, which is most abundant in plasma, pancreas and liver (Jońca et al., 2015). Jońca et al. (2015) stated that "BuChE serves as the first line of defence to the toxic compounds that reach the bloodstream that might inhibit AChE, the sister enzyme that located in the nervous system". Hence, $G$. manilaensis could be a weaker but safer anti-AChE agent compared to other algae.

Andriani et al. (2016) has reported hexanoic acid as the main contributor to the positive AChE inhibitory activity in their preliminary screening. In contrast, we have only discovered two fatty acids, 2-ethyl-dodecanoic acid and dioscoretine

\section{Data File \\ Sample Type \\ Instrument Name \\ Acq Method \\ IRM Calibration Status \\ Comment}

Sample Group

Stream Name

LC 1

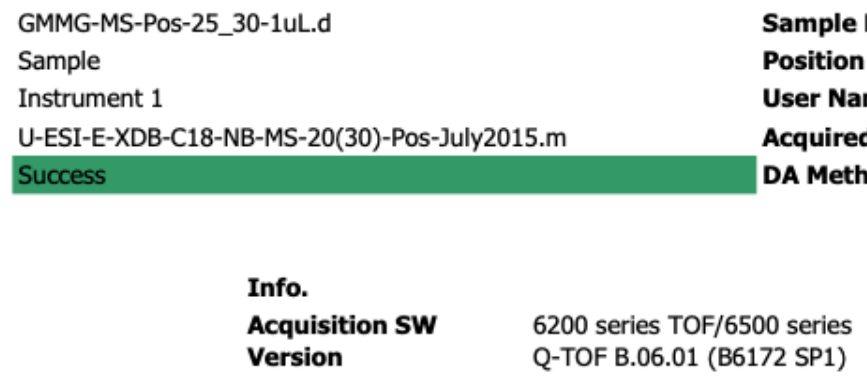

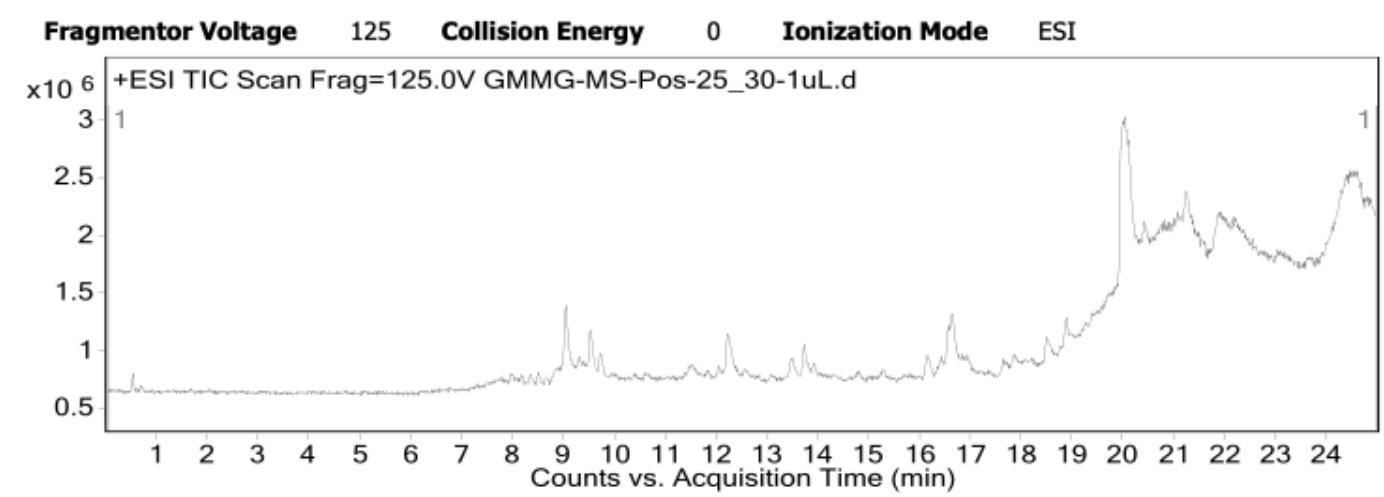

Fig. 8. LCMS chromatogram of GMMG. LCMS, liquid chromatography-mass spectrometry; GMMG, fraction G.

respectively (Suganthy et al., 2010). However, G. manilaensis did not show anti-BuChE activity compared to other red algae, postulating that the bioactive compounds that are responsible for anti-AChE activity in G. manilaensis are selective towards $\mathrm{AChE}$ but not BuChE. This finding revealed that G. manilaensis which do not have relevant activities to $\mathrm{AChE}$ and $\mathrm{BuChE}$, besides dioscoretine for its hypoglycaemic effect (Loizzo et al., 2017). On the other hand, ML-236C, C16 Sphignosine and 2,6-Nonadien-1-ol in GMMG also do not contain neuroprotective and ChEs inhibitory activity. ML-236C, also known 
as (4R,6R)-6-[2-[(1S,2S,8aR)-2-methyl-1,2,6,7,8,8a-hexahydronaphthalen-1-yl]ethyl]-4-hydroxyoxan-2-one, is a carbobicyclic compound with anti-cholesteremic activity that was isolated from fungus Pythium ultimum (Endo et al., 1976). C16 Sphignosine is a phospholipid that possesses anti-bacteria (Reid et al., 2019) and anti-cancer activities (Bagheri et al., 2018). 2,6-Nonadien-1-ol is a volatile fatty alcohol that function as a flavour compound described in many papers (Api et al., 2015, 2019; Flath et al., 1983; Kemp et al., 1974; McGinty et al., 2010).

The five neuroprotective compounds discovered in GMMG were drawn to our attention. Graveolinine is the only compound in GMMG that has been reported to positively inhibit AChE (Luo et al., 2020). Besides, graveolinine and its derivative also demonstrated neuroprotective activity against the neurotoxicity of $\beta$-amyloid and scopolamine (Luo et al., 2020). Meanwhile, cyneirne A (Marcotullio et al., 2006; Obara et al., 2007) and militarinone A (Küenzi et al., 2008; Riese et al., 2004; Schmidt et al., 2002) possess neurite outgrowth activity against PC12 cells. Interestingly, their respective derivatives, cyathane diterpene (Cao et al., 2018), as well as 4-hydroxy-2-pyridone (Schröder et al., 2015) and (+)-N-deoxymilitarinone A (Cheng et al., 2006) also displayed neurite outgrowth activity as their precursors. Curcumenol (Hamdi et al., 2015) and Eplerenone (Dong et al., 2012; Wang et al., 2020) are also neuroprotective towards neuronal cell lines and mouse brain. Curcumenol also shown anti-neuroinflammatory activity against LPS-stimulated murine BV2 microglia (Hsiao et al., 2020; Lo et al., 2015; Pintatum et al., 2020; Tanaka et al., 2008), whereby eplerenone shown anti-inflammatory activity to a variety of illnesses and conditions such as viral myocarditis (Xiao et al., 2009), heart-related inflammations (Chen et al., 2018; Łabuzek et al., 2014; Suzuki et al., 2006), renal inflammation (Bayorh et al., 2012; Chen et al., 2013) and obesity-associated inflammasome (Vecchiola et al., 2020; Wada et al., 2017). These compounds made GMMG a very promising neuroprotective fraction to be used as nutraceutical agents for neuronal health.

Our findings disclosed that GMM and GMMG of G. manilaensis possessed inhibitory activity to $\mathrm{AChE}$ but not BuChE. GMM and GMMG showed mixed inhibition and uncompetitive inhibition to the AChE activity respectively. The anti-AChE activity of GMMG is likely to be contributed by graveolinine. Taking together, graveolinine from G. manilaensis can be a promising lead compound for the development of anti-Alzheimer medicine in future. However, it is crucial to further validate the cholinesterase inhibitory activities of $G$. manilaensis in ani- mal cell culture in vitro and in vivo assays.

\section{Competing interests}

No potential conflict of interest relevant to this article was reported.

\section{Funding sources}

This research was funded by Sunway Internal Research Grants (Project No: INT-FST-DBS-2016-1, INTS-2017-SST-DBS-01 and INTS-2018-SST-DBS-09) from Sunway University and Jeffery Cheah Foundation Scholarship.

\section{Acknowledgements}

Not applicable.

\section{Availability of data and materials}

Upon reasonable request, the datasets of this study can be available from the corresponding author.

\section{Ethics approval and consent to participate}

This research has been approved by Sunway University Research Ethics Committee (Ethical Application Ref: PGSUREC2017/030).

\section{ORCID}

Jun-Rui Pang

https://orcid.org/0000-0002-8153-9758

Sher-Wei How https://orcid.org/0000-0002-7607-1644

Kah-Hui Wong https://orcid.org/0000-0002-8292-4498

Siew-Huah Lim https://orcid.org/0000-0003-1488-1307

Siew-Moi Phang https://orcid.org/0000-0001-8324-2432

Yoon-Yen Yow https://orcid.org/0000-0002-3859-2094

\section{References}

Alzheimer's Association Report. 2021 Alzheimer's disease facts and figures. J Alzheimer Dement. 2021;17:327-406.

An ZY, Yan YY, Peng D, Ou TM, Tan JH, Huang SL, et al. Synthesis and evaluation of graveoline and graveolinine derivatives with potent anti-angiogenesis activities. Eur J Med Chem. 2010; 45:3895-903.

Andriani Y, Syamsumir DF, Yee TC, Harisson FS, Herng GM, Abdullah SA, et al. Biological activities of isolated compounds from three edible Malaysian red seaweeds, Gracilaria changii, G. manilaensis and Gracilaria sp. Nat Prod Commun. 2016;11:1117-20. 
Api AM, Belsito D, Bhatia S, Bruze M, Calow P, Dagli ML, et al. RIFM fragrance ingredient safety assessment, (2E,6Z)nona-2,6-dien-1-ol, CAS registry number 28069-72-9. Food Chem Toxicol. 2015;84:S57-65.

Api AM, Belsito D, Botelho D, Bruze M, Burton GA Jr, Buschmann J, et al. RIFM fragrance ingredient safety assessment,(E,Z)-2,6-nonadien-1-ol acetate, CAS registry number 68555-65-7. Food Chem Toxicol. 2019;127:S216-23.

Bagheri E, Hajiaghaalipour F, Nyamathulla S, Salehen NA. Ethanolic extract of Brucea javanica inhibit proliferation of HCT-116 colon cancer cells via caspase activation. RSC Advances. 2018;8:681-9.

Bayorh M, Rollins-Hairston A, Adiyiah J, Lyn D, Eatman D. Eplerenone inhibits aldosterone-induced renal expression of cyclooxygenase. J Renin Angiotensin Aldosterone Syst. 2012;13:353-9.

Cao CY, Zhang CC, Shi XW, Li D, Cao W, Yin X, et al. Sarcodonin $G$ derivatives exhibit distinctive effects on neurite outgrowth by modulating NGF signaling in PC12 cells. ACS Chem Neurosci. 2018;9:1607-15.

Chen B, Geng J, Gao SX, Yue WW, Liu Q. Eplerenone modulates interleukin-33/sST2 signaling and IL-1 $\beta$ in left ventricular systolic dysfunction after acute myocardial infarction. J Interferon Cytokine Res. 2018;38:137-44.

Chen H, Sun F, Zhong X, Shao Y, Yoshimura A, Liu Y, et al. Eplerenone-mediated aldosterone blockade prevents renal fibrosis by reducing renal inflammation, interstitial cell proliferation and oxidative stress. Kidney Blood Press Res. 2013;37:557-66.

Cheng Y, Schneider B, Riese U, Schubert B, Li Z, Hamburger M. (+)-N-Deoxymilitarinone A, a neuritogenic pyridone alkaloid from the insect pathogenic fungus Paecilomyces farinosus. J Nat Prod. 2006;69:436-8.

Colović MB, Krstić DZ, Lazarević-Pašti TD, Bondžić AM, Vasić VM. Acetylcholinesterase inhibitors: pharmacology and toxicology. Curr Neuropharmacol. 2013;11:315-35.

Dong F, Xie W, Strong JA, Zhang JM. Mineralocorticoid receptor blocker eplerenone reduces pain behaviors in vivo and decreases excitability in small-diameter sensory neurons from local inflamed dorsal root ganglia in vitro. Anesthesiology. 2012;117:1102-12.

Endo A, Kuroda M, Tsujita Y. ML-236A, ML-236B, and ML236C, new inhibitors of cholesterogenesis produced by Penicillium citrinium. J Antibiot. 1976;29:1346-8.

Flath RA, Mon TR, Lorenz G, Whitten J, Mackley JW. Volatile components of Acacia sp. blossoms. J Agric Food Chem. 1983;31:1167-70.

Gutiérrez M, Matus MF, Poblete T, Amigo J, Vallejos G, Astudillo L, et al. Isoxazoles: synthesis, evaluation and bioinformatic design as acetylcholinesterase inhibitors. J Pharm Pharmacol. 2013;65:1796-804.

Ferreira-Vieira TH, Guimaraes IM, Silva FR, Ribeiro FM. Alzheimer's disease: targeting the cholinergic system. Curr Neuropharmacol. 2016;14:101-15.

Hamdi OAA, Ye LJ, Kamarudin MNA, Hazni H, Paydar M, Looi CY, et al. Neuroprotective and antioxidant constituents from Curcuma zedoaria rhizomes. Rec Nat Prod. 2015;9:349-55.

Hsiao JW, Chen LC, Lin CL, Chang TH, Chen CL, Sung PJ, et al. A new sesquiterpenoid and bioactive constituents of Curcuma zedoaria. Chem Nat Compd. 2020;56:1076-80.

Hung SY, Fu WM. Drug candidates in clinical trials for Alzheimer's disease. J Biomed Sci. 2017;24:47.

Jońca J, Żuk M, Wasąg B, Janaszak-Jasiecka A, Lewandowski K, Wielgomas B, et al. New insights into butyrylcholinesterase activity assay : serum dilution factor as a crucial parameter. PLOS ONE. 2015;10:e0139480.

Kandiah N, Pai MC, Senanarong V, Looi I, Ampil E, Park KW, et al. Rivastigmine: the advantages of dual inhibition of acetylcholinesterase and butyrylcholinesterase and its role in subcortical vascular dementia and Parkinson's disease dementia. Clin Interv Aging. 2017;12:697-707.

Kannan RRR, Aderogba MA, Ndhlala AR, Stirk WA, Van Staden J. Acetylcholinesterase inhibitory activity of phlorotannins isolated from the brown alga, Ecklonia maxima (Osbeck) Papenfuss. Food Res Int. 2013;54:1250-4.

Kemp TR, Knavel DE, Stoltz LP. Identification of some volatile compounds from cucumber. J Agric Food Chem. 1974;22:717-8.

Kihara T, Shimohama S. Alzheimer's disease and acetylcholine receptors. Acta Neurobiol Exp. 2004;64:99-105.

Küenzi P, Kiefer S, Koryakina A, Hamburger M. Promotion of cell death or neurite outgrowth in PC-12 and N2a cells by the fungal alkaloid militarinone A depends on basal expression of p53. Apoptosis. 2008;13:364-76.

Łabuzek K, Liber S, Bułdak Ł, Krupej-Kędzierska J, Machnik G, Bobrzyk M, et al. Eplerenone mimics features of the alternative activation in macrophages obtained from patients with heart failure and healthy volunteers. Eur J Pharmacol. 2014;726:96-108. 
Lo JY, Kamarudin MNA, Hamdi OAA, Awang K, Kadir HA. Curcumenol isolated from Curcuma zedoaria suppresses Akt-mediated NF- $\kappa$ B activation and p38 MAPK signaling pathway in LPS-stimulated BV-2 microglial cells. Food Funct. 2015;6:3550-9.

Loizzo MR, Bonesi M, Nabavi SM, Sobarzo-Sánchez E, Rastrelli L, Tundis R, et al. Hypoglycaemic effects of plants food constituents via inhibition of carbohydrate-hydrolysing enzymes: from chemistry to future applications. In: Andrade PB, Valentão P, Pereira DM, editors. Natural products targeting clinically relevant enzymes. Weinheim, Germany: Wiley-VCH; 2017. p 135-53.

Lombardo S, Maskos U. Role of the nicotinic acetylcholine receptor in Alzheimer's disease pathology and treatment. Neuropharmacology. 2015;96:255-62.

Luo W, Lv JW, Wang T, Zhang ZY, Guo HY, Song ZY, et al. Synthesis, in vitro and in vivo biological evaluation of novel graveolinine derivatives as potential anti-Alzheimer's agents. Bioorg Med Chem. 2020;28:115190.

Machado LP, Carvalho LR, Young MCM, Cardoso-Lopes EM, Centeno DC, Zambotti-Villela L, et al. Evaluation of acetylcholinesterase inhibitory activity of Brazilian red macroalgae organic extracts. Rev Bras Farmacogn. 2015;25:657-62.

Marcotullio MC, Mwankie GNO-M, Cossignani L, Tirillini B, Pagiotti R. Phytochemical analysis and antiradical properties of Sarcodon imbricatus (L.:Fr) Karsten. Nat Prod Commun. 2008;3:1907-10.

Marcotullio MC, Pagiott R, Maltese F, Obara Y, Hoshino T, Nakahata $\mathrm{N}$, et al. Neurite outgrowth activity of cyathane diterpenes from Sarcodon cyrneus, cyrneines A and B. Planta Med. 2006;72:819-23.

McGinty D, Letizia CS, Api AM. Fragrance material review on (2E,6Z)-nona-2,6-dien-1-ol. Food Chem Toxicol. 2010;48:S91-2.

Mielke MM, Leoutsakos JM, Corcoran CD, Green RC, Norton MC, Welsh-Bohmer KA, et al. Effects of food and drug administration-approved medications for Alzheimer's disease on clinical progression. Alzheimers Dement. 2012;8:180-7.

Ng PK, Lin SM, Lim PE, Hurtado AQ, Phang SM, et al. Genetic and morphological analyses of Gracilaria firma and G. changii (Gracilariaceae, Rhodophyta), the commercially important agarophytes in western Pacific. PLOS ONE. 2017;12:1-21.

Nitthithanasilp S, Intaraudom C, Boonyuen N, Suvannakad R, Pittayakhajonwut P. Antimicrobial activity of cyathane derivatives from Cyathus subglobisporus BCC44381. Tetrahedron. 2018;74:6907-16.

Obara Y, Hoshino T, Marcotullio MC, Pagiotti R, Nakahata N. A novel cyathane diterpene, cyrneine $\mathrm{A}$, induces neurite outgrowth in a Rac1-dependent mechanism in PC12 cells. Life Sci. 2007;80:1669-77.

Okubo H, Inagaki H, Gondo Y, Kamide K, Ikebe K, Masui Y, et al. Association between dietary patterns and cognitive function among 70-year-old Japanese elderly: a cross-sectional analysis of the SONIC study. Nutr J. 2017;16:56.

Pang JR, Goh VMJ, Tan CY, Phang SM, Wong KH, Yow YY, et al. Neuritogenic and in vitro antioxidant activities of Malaysian Gracilaria manilaensis Yamamoto \& Trono. J Appl Phycol. 2018;30:3253-60.

Pangestuti R, Kim SK. Neuroprotective effects of marine algae. Mar Drugs. 2011;9:803-18.

Phang SM, Yeong HY, Lim PE. The seaweed resources of Malaysia. Bot Mar. 2019;62:265-73.

Pintatum A, Maneerat W, Logie E, Tuenter E, Sakavitsi ME, Pieters $\mathrm{L}$, et al. In vitro anti-inflammatory, anti-oxidant, and cytotoxic activities of four Curcuma species and the isolation of compounds from Curcuma aromatica rhizome. Biomolecules. 2020;10:799.

Reid T, Kashangura C, Chidewe C, Benhura MA, Stray-Pedersen B, Mduluza T, et al. Characterization of anti-Salmonella typhi compounds from medicinal mushroom extracts from Zimbabwe. Int J Med Mushrooms. 2019;21:713-24.

Riese U, Ziegler E, Hamburger M. Militarinone A induces differentiation in PC12 cells via MAP and Akt kinase signal transduction pathways. FEBS Lett. 2004;577:455-9.

Ruangritchankul S, Chantharit P, Srisuma S, Gray LC. Adverse drug reactions of acetylcholinesterase inhibitors in older people living with dementia: a comprehensive literature review. Ther Clin Risk Manag. 2021;17:927-49.

Schmidt K, Günther W, Stoyanova S, Schubert B, Li Z, Hamburger M, et al. Militarinone A, a neurotrophic pyridone alkaloid from Paecilomyces militaris. Org Lett. 2002;4:197-9.

Schröder P, Förster T, Kleine S, Becker C, Richters A, Ziegler S, et al. Neuritogenic militarinone-inspired 4-hydroxypyridones target the stress pathway kinase MAP4K4. Angew Chem Int Ed Engl. 2015;54:12398-403.

Senevirathne M, Ahn CB, Je JY. Enzymatic extracts from edible red algae, Porphyra tenera, and their antioxidant, anti-acetylcholinesterase, and anti-inflammatory activities. Food Sci Biotechnol. 2010;19:1551-7. 
Silverthorn DU. Neruons: Cellular and network properties. In: Human Physiology: An Integrated Approach. London: Pearson; 2016. p. 277-84.

Suganthy N, Karutha Pandian S, Pandima Devi K. Neuroprotective effect of seaweeds inhabiting South Indian coastal area (Hare Island, Gulf of Mannar Marine Biosphere Reserve): cholinesterase inhibitory effect of Hypnea valentiae and Ulva reticulata. Neurosci Lett. 2010;468:216-9.

Suzuki J, Iwai M, Mogi M, Oshita A, Yoshii T, Higaki J, et al. Eplerenone with valsartan effectively reduces atherosclerotic lesion by attenuation of oxidative stress and inflammation. Arterioscler Thromb Vasc Biol. 2006;26:917-21.

Syad AN, Rajamohamed BS, Shunmugaiah KP, Kasi PD. Neuroprotective effect of the marine macroalga Gelidiella acerosa: identification of active compounds through bioactivity-guided fractionation. Pharm Biol. 2016;54:2073-81.

Syad AN, Shunmugiah KP, Kasi PD. Assessment of anticholinesterase activity of Gelidiella acerosa : implications for its therapeutic potential against Alzheimer's disease. Evid Based Complement Alternat Med. 2012;2012:497242.

Tanaka K, Kuba Y, Ina A, Watanabe H, Komatsu K. Prediction of cyclooxygenase inhibitory activity of Curcuma rhizome from chromatograms by multivariate analysis. Chem Pharm Bull. 2008;56:936-40.

Tsuno N. Donepezil in the treatment of patients with Alzheimer's disease. Expert Rev Neurother. 2009;9:591-8.

Vecchiola A, Fuentes CA, Solar I, Lagos CF, Opazo MC, Muñoz-Durango N, et al. Eplerenone implantation improved adipose dysfunction averting RAAS activation and cell division. Front Endocrinol. 2020;11:223.

Wada T, Ishikawa A, Watanabe E, Nakamura Y, Aruga Y, Hasegawa $\mathrm{H}$, et al. Eplerenone prevented obesity-induced inflammasome activation and glucose intolerance. J Endocrinol. 2017;235:179-91.

Wang B, Han J, Xu W, Chen Y, Liu, H. Production of bioactive cyathane diterpenes by a bird's nest fungus Cyathus gansuensis growing on cooked rice. Food Chem. 2014;152:16976.

Wang X, Zhu Y, Wang S, Wang Z, Sun H, He Y, et al. Effects of eplerenone on cerebral aldosterone levels and brain lesions in spontaneously hypertensive rats. Clin Exp Hypertens. 2020;42:531-8.

World Health Organisation. Dementia. 2021 [cited 2021 Aug 21]. https://www.who.int/news-room/fact-sheets/detail/ dementia
Wu TS, Shi LS, Wang JJ, Iou SC, Chang HC, Chen YP, et al. Cytotoxic and antiplatelet aggregation principles of Ruta graveolens. J Chin Chem Soc. 2003;50:171-8.

Xiao J, Shimada M, Liu W, Hu D, Matsumori A. Anti-inflammatory effects of eplerenone on viral myocarditis. Eur J Heart Fail. 2009;11:349-53.

Yoon NY, Chung HY, Kim HR, Choi JE. Acetyl- and butyrylcholinesterase inhibitory activities of sterols and phlorotannins from Ecklonia stolonifera. Fish Sci. 2008;74:200-7.

Yoon NY, Lee SH, Yong-Li, Kim SK. Phlorotannins from Ishige okamurae and their acetyl- and butyrylcholinesterase inhibitory effects. J Funct Foods. 2009;1:331-5.

Yow YY, Lim PE, Phang SM. Assessing the use of mitochondrial cox1 gene and cox2-3 spacer for genetic diversity study of Malaysian Gracilaria changii (Gracilariaceae, Rhodophyta) from Peninsular Malaysia. J Appl Phycol. 2013;25:831-8. 